ROZ D Z I A 16 .

\title{
PRZEDSIĘBIORCZOŚĆ NA OBSZARACH WIEJSKICH WOJEWÓDZTWA PODLASKIEGO -WCZORAJ I DZIŚ
}

\author{
Renata Przygodzka ${ }^{1}$
}

\section{Wstęp}

Obszary wiejskie, definiowane w najbardziej ogólny sposób, jako tereny poza granicami administracyjnymi miast ${ }^{2}$, stanowią w Polsce około

\footnotetext{
${ }^{1}$ Dr hab. Renata Przygodzka, prof. UwB, Uniwersytet w Białymstoku.

${ }^{2}$ Wszelka działalność ludzka odbywa się w przestrzeni, może być w niej rozproszona lub skupiona w dogodnych punktach. Z chwilą powstania miast ogniskowały się w nich różnorodne zajęcia, interesy, wzajemne kontakty i współzależności określające charakter i funkcje miasta. Na wsi rodzaj wykonywanych czynności był mniej zróżnicowany i zdominowany na ogół przez pracę w rolnictwie i innych działach opartych na eksploatacji zasobów naturalnych. Ta dwoistość miejskiego i wiejskiego bytowania, mimo dużych zmian i zacierania niektórych różnic, utrzymała się do dzisiaj, aczkolwiek coraz częściej podkreśla się postępujący proces dezagraryzacji wsi czy też zmiany jej funkcji. Zob. szerzej M. Stanny, Wieś, obszar wiejski, ludność wiejska - o problemach z ich definiowaniem. Wielowymiarowe spojrzenie, „Wieś i Rolnictwo” 2014, nr 1(62), s. 123-128.

Pojęcie miasta i wsi przyjmuje różną treść w poszczególnych krajach. Dla dokonania podziału osiedli na wieś i miasto mogą być stosowane różne kryteria takie, jak: liczba ludności, gęstość zaludnienia, zainwestowanie w zabudowę i urządzenia trwałe, stopień przestrzennej koncentracji zabudowy, sposób użytkowania ziemi, struktura społeczno-zawodowa ludności, rodzaj więzi społecznych, występowanie funkcji nadrzędnych i inne. Tak więc podział na obszary miejskie
} 
93\% ogólnej powierzchni kraju, a zamieszkiwane są przez prawie 40\% populacji ${ }^{3}$. Na aktywność gospodarczą obszarów wiejskich można patrzeć z perspektywy różnych aspektów, jednak kluczowe znaczenie odgrywają dwa procesy: rozwój rolnictwa oraz rozwój pozarolniczej działalności gospodarczej.

Tradycyjnie, jako dominującą funkcję obszarów wiejskich postrzega się rolnictwo. W 2016 roku w Polsce sektor ten obejmował ok. 1,4 mln gospodarstw rolnych o łącznej powierzchni 16,1 mln ha stanowiącej $55,2 \%$ powierzchni obszarów wiejskich ${ }^{4}$. Jednak jego udział w tworzeniu PKB wynosi obecnie $2,6 \% \mathrm{PKB}^{5}$, w zatrudnieniu $-11 \%{ }^{6}$, a dochody z produkcji rolniczej są głównym źródłem utrzymania dla niespełna $10 \%$ ludności wsi ${ }^{7}$. Zatem znaczenie rolnictwa jako funkcji obszarów wiejskich systematycznie się zmniejsza. Z danych statystycznych wynikało, że coraz większą rolę w kształtowaniu aktywności ekonomicznej mieszkańców wsi odgrywa działalność pozarolnicza. Jej rozwój, stymulowany w trojaki

i wiejskie rozpatrywany jest najczęściej w aspektach geograficzno-przestrzennych, ekonomicznych i socjologiczno-kulturowych, i dostosowany jest do potrzeb administracyjno-prawnych różnych krajów. W Polsce poszczególnym osiedlom wiejskim w miarę ich rozwoju ludnościowego i poszerzania spełnianych przezeń funkcji, przyznaje się mocą decyzji administracyjnej prawa miejskie, a podział na wieś i miasto jest bezpośrednio związany z podziałem administracyjnym. Por. m.in. M. Adamowicz, Przemiany strukturalne obszarów wiejskich $w$ krajach europejskich jako podstawa polityki regionalnej, opracowanie wykonane $\mathrm{w}$ ramach projektu badawczego nr 5028191 01, Warszawa 1992, s. 1-3.

${ }^{3}$ Obszary wiejskie $w$ Polsce $w 2016$ roku, GUS, Warszawa 2017, s. 21.

${ }^{4}$ Tamże, s. 21.

${ }^{5}$ Produkt krajowy brutto i wartość dodana brutto w przekroju regionów $w 2016$ roku, Informacje sygnalne, GUS, Warszawa 2018, s. 4, https://stat.gov.pl/download/ gfx/portalinformacyjny/pl/defaultaktualnosci/5482/7/1/1/pkb_i_wartosc_dodana_brutto_w_przekroju_regionow_w_2016.pdf [data dostępu: 27.09.2019].

${ }^{6}$ W II kwartale 2019 roku liczba pracujących w rolnictwie, leśnictwie i rybactwie wynosiła 1484 mln osób, https://rynekpracy.org/statystyki/pracujacy-w -rolnictwie-przemysle-i-uslugach [data dostępu: 26.09.2019].

${ }^{7}$ Polska wieś 2018. Raport o stanie wsi, J. Wilkin, I. Nurzyńska (red.), Wydawnictwo Naukowe Scholar, Warszawa 2018, s. 13. 
sposób: po pierwsze - za pomocą wsparcia publicznego finansowanego z funduszy unijnych, w tym przede wszystkim w ramach Wspólnej Polityki Rolnej, po drugie - poprzez wzrost popytu na różne dobra i usługi generowany przez mieszkańców wsi, a po trzecie - napływ mieszkańców miast, oddziałuje na wiejski rynek pracy i dywersyfikuje źródła dochodów ludności ${ }^{8}$.

Z Raportu „Wieś w Polsce 2017: diagnoza i prognoza”9 wynika, że „eksperci zgodnie przyznają, iż aktywność pozarolnicza na wsi będzie w przyszłości odgrywać coraz większą rolę”, aczkolwiek „z trudnością przychodzi im opisywanie struktury przedsiębiorstw na wsi poza rolnictwem". Oznacza to, że nadal przedsiębiorczość na obszarach wiejskich nie jest do końca zbadanym zjawiskiem. Ponad 25 lat temu, autorka niniejszego opracowania, w związku z realizacją badań na potrzeby pracy doktorskiej $^{10}$, przedsiębiorczość wiejską traktowała jako źródło czy też czynnik sprawczy wielofunkcyjnego rozwoju obszarów wiejskich, który to rozwój w wąskim ujęciu rozumiała jako proces tworzenia pozarolniczych miejsc pracy. Ciekawość badawcza zrodziła następujące pytania: czy i w jakim stopniu zmieniły się poziom i struktura przedsiębiorczości na obszarach wiejskich województwa podlaskiego, które objęto badaniami

${ }^{8}$ R. Marks-Bielska podkreśla także szczególną rolę samorządu gminnego. Zob. R. Marks-Bielska, The role of local authorities in creating conditions for the development of economic activities: a case study of rural municipalities in Poland, Proceedings of the 8 th International Scientific Conference Rural Development 2017. Edited by prof. A. Raupeliene; R. Marks-Bielska, M. Wojarska, I. Serocka, Importance of Measures Taken by Local Authorities for Development of Entrepreneurship - a Case Study of Rural Municipalities in Poland. Proceedings of the 2019 International Conference "Economic Science for Rural Development", Jelgava, LLU ESAF, 9-10 May 2019, nr 50, s. 132-139; Przedsiębiorczość gospodarcza a rozwój lokalny, R. Marks-Bielska (red.), Wydawnictwo Informatyczny Ekspert, Olsztyn 2016.

${ }^{9}$ Wieś $w$ Polsce 2017: diagnoza i prognoza, Fundacja Wspomagania Wsi, Warszawa 2017, s. 29.

${ }^{10}$ R. Przygodzka, Zasoby pracy a wielofunkcyjny rozwój obszarów wiejskich, rozprawa doktorska, Filia Uniwersytetu Warszawskiego w Białymstoku, Białystok 1996. 
w roku 1995 (wówczas województwo białostockie)? Czy tempo tych zmian jest zbliżone do przeciętnych zmian w Polsce, czy też może się różni? Jak zmieniały się podstawowe wskaźniki opisujące przedsiębiorczość w wybranych do badań gminach? Chęć znalezienia odpowiedzi na powyższe pytania stała się inspiracją dla przeprowadzenia badań porównawczych. Zatem celem niniejszego rozdziału jest identyfikacja kluczowych zmian w rozwoju przedsiębiorczości na obszarach wiejskich województwa podlaskiego, jakie miały miejsce w latach 1995-2018.

Do realizacji celu, w części teoretycznej, wykorzystano studia literatury przedmiotu zarówno krajowej, jak i zagranicznej, analizę raportów i opracowań instytucji rządowych: Agencji Restrukturyzacji i Modernizacji Rolnictwa (ARiMR), Polskiej Agencji Rozwoju Przedsiębiorczości (PARP) oraz instytucji naukowych: Instytutu Rozwoju Wsi i Rolnictwa (IRWiR PAN) i Instytutu Ekonomiki Rolnictwa i Gospodarki Żywnościowej (IERiGŻ). Natomiast w części empirycznej wykorzystano przede wszystkim dane wtórne. Ich głównym źródłem był Bank Danych Lokalnych oraz inne informacje zgromadzone przez Główny Urząd Statystyczny.

Jak wcześniej wspomniano, zasięg terytorialny badań został ograniczony do województwa podlaskiego, a ich uszczegółowienie - do sześciu celowo wybranych gmin tego regionu. Za takim postępowaniem przemawia przede wszystkim fakt, że w wyniku reformy administracyjnej, która weszła w życie z dniem 1 stycznia 1999 roku województwo białostockie, w którym pierwotnie były realizowane badania, zostało rozszerzone i „wchłonęło" wcześniejsze województwa łomżyńskie i suwalskie, przyjmując nazwę województwa podlaskiego. Oznacza to, że wiele wskaźników byłoby nieporównywalnych. W związku z powyższym, dane prezentowane w układzie wojewódzkim, dotyczyć będą ostatnich lat. Natomiast bardziej szczegółowa analiza, obejmująca lata 1995-2018, została przeprowadzona - jak już podkreślono - w sześciu gminach województwa podlaskiego. Niewątpliwie wiele ze wskaźników, które opisywały sytuację społeczno-ekonomiczną powyższych gmin, po upływie 25 lat uległo zmianie. Niemniej jednak interesujące jest, czy i jak w tak zróżnicowanych gminach, rozwijała się w ciągu ostatnich 25 lat wiejska przedsiębiorczość. 


\subsection{Istota przedsiębiorczości wiejskiej i jej uwarunkowania}

Pojęcie przedsiębiorczości jest bardzo złożone. Rozumiane jest ono w rozmaity sposób i dotyczy zarówno podmiotów zbiorowych jak i indywidualnych. Najszersze ujęcie przedsiębiorczości określa ją jako całokształt indywidualnych i zbiorowych działań, które przełamują istniejące wzorce gospodarowania ${ }^{11}$. Przedsiębiorczość polega więc na krytyce istniejącego stanu rzeczy i poszukiwaniu, obarczonym ryzykiem, nieszablonowych sposobów jego zmiany.

Niektórzy autorzy nie wiążą pojęcia przedsiębiorczości z działalnością na rachunek własny, lecz z człowiekiem, jego aktywnością, twórczością, innowacyjnością bez względu na formę organizacyjno-własnościową danej instytucji gospodarczej ${ }^{12}$. Józef Pajestka zwraca uwagę, iż w ekonomicznych zachowaniach ludzi aktywność, twórczość, racjonalność i innowacyjność, nie są cechami naturalnymi, przyrodzonymi społeczeństwom i narodom. Są one produktami kulturowymi, a więc muszą być wykształcone i pielęgnowane ${ }^{13}$. Powyższe potwierdza również Peter F. Drucker podkreślając, że innowacja i przedsiębiorczość to celowe zadania, które można organizować i którym potrzebne jest organizowanie oraz, że należy je traktować jako systematyczną pracę ${ }^{14}$.

Przedsiębiorczość - zdaniem Tadeusza Hunka - polega na organizacji i kierowaniu przedsiębiorstwem, firmą, przedsięwzięciem, opartym na motywach zysku. Motyw zysku, przy założeniu ryzyka i na własną odpowiedzialność, w gospodarce rynkowej jest socjologicznie szeroki i nie

${ }^{11}$ Por. L. Bylicki, Kontrowersje wokót pojęcia przedsiębiorczości, [w:] Alternatywne źródła dochodów ludności wiejskiej, Biuletyn Regionalny Zakładu Doradztwa Rolniczego, nr 309, Akademia Rolnicza im. H. Kołłątaja, Kraków 1994, s. 43-44.

12 A. Sadowski, Przedsiębiorstwo i przedsiębiorczość $w$ warunkach integracji, A. Sadowski (red.), Fundacja Promocji Rozwoju Podlasia, Białystok 2008.

13 Zob. J. Pajestka, Reforma gospodarcza na nowym etapie, Studia i Materiały, nr 7, INE PAN, Warszawa 1988, s. 26.

${ }^{14}$ Por. P.F. Drucker, Innowacja i przedsiębiorczość. Praktyka i zasady, PWE, Warszawa 1992, s. 7. 
sprowadza się jedynie do ilościowo ujętej sumy pieniądza. Zysk stanowi parametr prestiżu określonej władzy nad ludźmi i rzeczami, formę personalnego dowartościowania. Zysk jest zatem kategorią społeczną i stąd jego rola jako katalizatora, czynnika mobilizującego i wyzwalającego energię, pomysłowość, wysiłek, kreującego różne formy działalności ludzkiej ${ }^{15}$. Natomiast według Jana Szczepańskiego podstawą tempa wzrostu gospodarczego nie jest bezwzględny egoizm przedsiębiorców i ich bezgraniczne dążenie do zysku czy innych korzyści społecznych, ale zaangażowanie indywidualnych zdolności, autonomii działania w opozycji do formalistycznego skrępowania. Zatem podstawową funkcją przedsiębiorczości jest przełamanie barier rozwojowych społeczeństwa lub kooperacji, a tym samym zapewnienie im zdolności do przetrwania, traktowanej współcześnie jako najlepszy miernik sprawności działania ${ }^{16}$. Wyrazem tak pojmowanej przedsiębiorczości jest aktywność w zakładaniu przedsiębiorstw, a jej miarą może być np. wskaźnik nasycenia podmiotami gospodarczymi.

Istotnym elementem przedsiębiorczości jest witalność, inicjatywa i gotowość do podjęcia ryzyka. Człowiek przedsiębiorczy to ten, który tworzy nowe rzeczy i uczestniczy w ich urzeczywistnianiu lub aktywnie oddziałuje na innych w celu realizacji nowej kombinacji czynników produkcji. Katarzyna Duczkowska-Małysz traktuje przedsiębiorczość jako cechę osobowości, skłonność, zdolność do przejawiania ducha inicjatywy i zaradność oraz jako proces polegający na podejmowaniu wszechstronnych działań związanych z przystosowaniem się do reguł i wymogów gospodarki rynkowej. W tym rozumieniu przedsiębiorczość dotyczy zarówno osób fizycznych, jak i prawnych ${ }^{17}$.

Już nawet ten krótki przegląd różnych podejść oraz ujęć pojęcia przedsiębiorczości wskazuje na znaczny stopień jego złożoności. W niniejszej

15 Por. T. Hunek, Makroekonomiczne uwarunkowania „small businessu” na terenach wiejskich, [w:] Przedsiębiorczość na obszarach..., s. 13.

${ }^{16}$ Zob. J. Szczepański, O indywidualności, PWN, Warszawa 1988, s. 18.

17 Zob. K. Duczkowska-Małysz, Uwarunkowania rozwoju przedsiębiorczości, [w:] Rozwój przedsiębiorczości na terenach wiejskich, K. Duczkowska-Małysz, M. Kłodziński (red.), Fundusz Współpracy, IRWiR PAN, Warszawa 1994, s. 14. 
pracy pojęcie to rozumiane jest jako proces, polegający na podejmowaniu działalności gospodarczej. Jest to pewne uproszczenie, jednakże niezbędne dla przejrzystości pracy.

Czym zatem jest przedsiębiorczość wiejska? W najbardziej ogólnym ujęciu jest to pozarolnicza działalność gospodarcza, podejmowana na obszarach wiejskich. W wąskim ujęciu natomiast jest to proces tworzenia na wsi pozarolniczych miejsc pracy, stanowiących alternatywne dla rolnictwa źródło dochodów. Przy czym - co istotne - takie miejsca mogą powstawać również w gospodarstwach rolnych (gospodarstwa wielofunkcyjne).

Ogół czynników oddziałujących na rozwój przedsiębiorczości na obszarach wiejskich można podzielić na makro- i mikroekonomiczne. Makroekonomiczne uwarunkowania wynikają z ogólnego poziomu rozwoju społeczno-gospodarczego kraju, z usytuowania rolnictwa i gospodarki żywnościowej w gospodarce narodowej, z kreowanej polityki ekonomicznej, z ukształtowanego systemu prawa i innych ${ }^{18}$.

Do mikroekonomicznych czynników determinujących rozwój pozarolniczej działalności gospodarczej zaliczyć można takie, jak: położenie gminy, historycznie ukształtowaną strukturę gospodarki, rangę i charakter rolnictwa w rozwoju mikroregionu, stan infrastruktury, sytuację demograficzną w gminie i poziom bezrobocia, strukturę społeczno-zawodową, stosunki własności i zasoby kapitału, sprawność instytucji wiejskich, w tym aktywności samorządów lokalnych i władz gminy, postawy społeczne, w szczególności do przedsiębiorczości.

Powyższe czynniki sklasyfikowane zostały przez K. Duczkowską-Małysz na podstawie ogólnopolskich interdyscyplinarnych badań nad rozwojem

18 Por. K. Duczkowska-Małysz, J. Małysz, Mikroekonomiczne uwarunkowania rozwoju przedsiębiorczości, [w:] Przedsiębiorczość na obszarach..., s. 26; konsekwencje dla rozwoju small businessu, wynikające z usytuowania rolnictwa i gospodarki żywnościowej, wymienia i opisuje T. Hunek, Drobna przedsiębiorczość (small business) na terenach wiejskich. Systemowe uwarunkowania rozwoju, „Wieś i Rolnictwo” 1995, nr 4, s. 129-130. 
przedsiębiorczości na terenach wiejskich ${ }^{19}$. Pomimo upływu czasu, nadal determinują aktywność gospodarczą mieszkańców wsi wyrażającą się w uruchamianiu i prowadzeniu działalności gospodarczeje ${ }^{20}$.

\subsection{Poziom i struktura przedsiębiorczości województwa podlaskiego na tle kraju}

Jedną z podstawowych miar rozwoju przedsiębiorczości jest liczba podmiotów gospodarki narodowej zarejestrowanych w systemie REGON (Krajowy Rejestr Urzędowy Podmiotów Gospodarki Narodowej). W dniu 31 lipca 2019 roku liczba ta w województwie podlaskim wynosiła 106042, co stanowiło 2,37\% ogółu podmiotów w kraju. Odsetek ten plasuje województwo na przedostatnim miejscu w kraju. Wprawdzie w porównaniu z 2000 rokiem nastąpił wzrost liczby zarejestrowanych podmiotów o $23 \%$, jednak dynamika ta nie wpłynęła $\mathrm{w}$ istotnym stopniu na poprawę pozycji analizowanego województwa w kraju.

Podobnie jak w Polsce, ponad 70\% ogółu podmiotów zarejestrowanych w województwie podlaskim funkcjonuje w miastach. Natomiast na obszarach wiejskich działalność prowadzi co trzeci podmiot. Taka struktura

${ }^{19}$ Zob. K. Duczkowska-Małysz, dz. cyt., s. 15.

${ }^{20}$ Zob. m.in. J. Bański, Uwarunkowania rozwoju przedsiębiorczości na wsi - wybrane zagadnienia, „Roczniki Naukowe Ekonomii Rolnictwa i Rozwoju Obszarów Wiejskich" 2015, t. 102, z. 1, s. 59-69; M. Bajgier-Kowalska, M. Tracz, R. Uliszak, Uwarunkowania rozwoju przedsiębiorczości na obszarach wiejskich na przykładzie gospodarstw agroturystycznych województwa małopolskiego, „Przedsiębiorczość -Edukacja" 2016, nr 12, s. 256-273; R. Majewski, J. Staniszewski, B. Czyżewski, Specyfika pozarolniczej dziatalności gospodarczej na wsi w kontekście jej wsparcia ze środków Unii Europejskiej, „Roczniki Ekonomiczne Kujawsko-Pomorskiej Szkoły Wyższej w Bydgoszczy" 2012, nr 5; W. Musiał, J. Barczyk, J. Zukovskis, Bariery i szanse rozwoju drobnej przedsiębiorczości na obszarach wiejskich $w$ Polsce i na Litwie w ocenach ekonomistów, „Zeszyty Naukowe Wydziału Nauk Ekonomicznych” 2018, nr 22; M. Kłodziński, Kształtowanie się rozwoju przedsiębiorczości wiejskiej na tle ogólnokrajowych i europejskich tendencji, „Roczniki Naukowe SERiA” 2015, t. XVII, z. 3. 
w istotnym stopniu wpływa na wskaźnik nasycenia podmiotami gospodarczymi. Na 1000 mieszkańców terenów wiejskich w 2016 roku przypadało 75 podmiotów, czyli prawie dwukrotnie mniej niż w miastach, gdzie wartość tego wskaźnika wynosiła 133. Analogiczny wskaźnik w województwie podlaskim należał do najniższych w kraju i wyniósł 57 (dla porównania można dodać, że w województwie zachodniopomorskim ukształtował się na poziomie 97$)^{21}$.

W 2016 roku w strukturze podmiotów gospodarki narodowej zlokalizowanych na obszarach wiejskich według klas wielkości największy odsetek stanowiły podmioty o liczbie pracujących do 9 osób - 96,1\%22. Prawidłowość ta dotyczyła wszystkich regionów w kraju. Natomiast w strukturze podmiotów gospodarki narodowej według form prawnych dominującą pozycję zajmowały osoby fizyczne prowadzące działalność gospodarczą - 79,7\% (w miastach - 66,5\%). W następnej kolejności znalazły się spółki handlowe $(5,8 \%)$, spółki cywilne $(4,2 \%)$ oraz stowarzyszenia i organizacje społeczne $(3,7 \%)^{23}$. Nieco odmiennie struktura ta wyglądała w województwie podlaskim. O ile udział osób fizycznych prowadzących działalność gospodarczą był zbliżony i wynosił - 79,1\%, to znacznie mniej odnotowano spółek handlowych $(3,8 \%)$, oraz spółek cywilnych $(2,9 \%)$, natomiast więcej (o 1,3 pkt. proc.) stowarzyszeń i organizacji społecznych. Oznacza to, że 4 na 5 podmiotów to mikrofirmy, których skala i obszar działania zazwyczaj mają charakter lokalny i w niewielkim stopniu oddziałują na rynek pracy, chociaż ich pozytywnym aspektem jest samozatrudnienie.

Biorąc pod uwagę rodzaj działalności prowadzony przez podmioty gospodarki narodowej funkcjonujące na obszarach wiejskich w Polsce w podziale na sekcje PKD 2007 odnotowano, że w 2016 roku najwięcej

${ }^{21}$ Obszary wiejskie $w$ Polsce $w$ 2016, GUS, Warszawa-Olsztyn 2018, s. 103.

22 Potwierdzają tę prawidłowość także badania prowadzone przez J. Bańskiego. Zob. szerzej: J. Bański, Uwarunkowania rozwoju przedsiębiorczości na wsi-wybrane zagadnienia, „Roczniki Naukowe Ekonomii Rolnictwa i Rozwoju Obszarów Wiejskich" 2015, t. 102, z. 1, s. 59-69.

23 Obszary wiejskie..., s. 104. 
podmiotów zajmowało się handlem i naprawą pojazdów samochodowych $24,7 \%$. Kolejne miejsce pod względem liczebności zajmowały podmioty prowadzące działalność budowlaną - 16,5\%, przemysłową - 12,1\%, transportową i magazynową $-7,0 \%$, pozostałą usługową $-6,4 \%$ oraz profesjonalną, naukową i techniczną - 6,2\%. Udziały pozostałych sekcji PKD 2007 nie przekroczyły $5,0 \%{ }^{24}$. W województwie podlaskim natomiast zaobserwowano nieco mniejszy udział podmiotów zajmujących się handlem i naprawą pojazdów samochodowych $(22,3 \%)$, także mniejszy udział firm prowadzących działalność przemysłową (10,5\%). Znacznie większy odsetek podmiotów zajmuje się z kolei rolnictwem, leśnictwem, łowiectwem i rybactwem (8,3\%). Jest to konsekwencją istotnie większej roli tego sektora w gospodarce regionu w porównaniu z resztą kraju. Świadczy o tym nie tylko relatywnie wysoki udział rolnictwa w tworzeniu wartości dodanej, który w 2016 roku wyniósł 6,5\% (zatem trzykrotnie więcej niż przeciętnie w Polsce) ${ }^{25}$, w zatrudnieniu - 29\% (dwukrotnie więcej niż w Polsce) ${ }^{26}$, ale także w kształtowaniu dochodów ludności wiejskiej: w 2016 roku działalność rolnicza stanowiła główne źródło dochodów (przekraczające 50\% dochodów ogółem) dla 45,6\% gospodarstw domowych z użytkownikiem gospodarstwa indywidualnego (czyli gospodarstw rolnych) ${ }^{27}$.

Generalnie z przeprowadzonych rozważań wynika, że pozarolnicza działalność gospodarcza na obszarach wiejskich województwa podlaskiego w zakresie struktury rozpatrywanej zarówno w odniesieniu do form

\footnotetext{
24 Tamże, s. 106.
}

${ }^{25}$ Produkt krajowy brutto i wartość dodana brutto w przekroju regionów w 2016 roku, Informacje sygnalne, GUS, Warszawa 2018, s. 4, https://stat.gov.pl/download/ gfx/portalinformacyjny/pl/defaultaktualnosci/5482/7/1/1/pkb_i_wartosc_dodana_brutto_w_przekroju_regionow_w_2016.pdf [data dostępu: 27.09.2019].

${ }^{26}$ Rocznik statystyczny województw w 2018 roku, GUS, Warszawa 2019, s. 246.

27 Oczywiście, działalność rolnicza nie we wszystkich gospodarstwach stanowiła główne źródło dochodów. Znaczna ich część utrzymywała się głównie z pracy najemnej $(27,5 \%)$ oraz emerytury i renty $(8,9 \%)$, zob. Charakterystyka gospodarstw rolnych $w$ województwie podlaskim $w 2016$ roku, Urząd Statystyczny w Białymstoku, Białystok 2017, s. 4. 
organizacyjno-prawnych, jak i branżowej, jest zbliżona do wskaźników przeciętnych dla kraju. Natomiast niskie są, o czym należy pamiętać, zarówno liczba podmiotów prowadzących działalność na tych terenach, jak i wskaźnik nasycenia podmiotami gospodarczymi. A zatem można stwierdzić, że poziom wiejskiej przedsiębiorczości w analizowanym regionie jest relatywnie niski. Nie oznacza to jednak, że niski jest poziom aktywności ekonomicznej mieszkańców wsi. Świadczą o tym m.in. wysoki współczynnik aktywności zawodowej, czy wskaźnik zatrudnienia, które plasują województwo na 8 miejscu w kraju ${ }^{28}$. Na szczególne podkreślenie zasługuje natomiast swoista przedsiębiorczość i aktywność podlaskich rolników. Wyraża się ona w aplikowaniu o środki unijne. W zasadzie w większości działań Programu Rozwoju Obszarów Wiejskich na lata 2014-2020 skierowanych do gospodarstw rolnych, rolnicy z województwa podlaskiego zajmują czołowe miejsca zarówno w składaniu wniosków, jak i w uzyskiwaniu wsparcia. Na przykład w działaniu „Inwestycje w środki trwałe" rolnicy z badanego województwa złożyli 5541 wniosków (czyli 9\% ogółu), na kwotę 1,27 mld zł, natomiast liczba tzw. umów czynnych w tym działaniu wynosi 2718 na kwotę prawie 600 mln zł (11\% ogólnej kwoty czynnych umów i jednocześnie 1 miejsce w Polsce) ${ }^{29}$. Z uwagi na rozwój pozarolniczej aktywności na obszarach wiejskich, szczególne znaczenie mają dwa działania, a mianowicie „Premie na rozpoczęcie działalności pozarolniczej” oraz „Rozwój przedsiębiorczości - rozwój usług rolniczych". W pierwszym z nich podlascy rolnicy złożyli 674 wnioski (8\%) na kwotę 121,2 mln zł, natomiast pozytywne decyzje uzyskały 153 wnioski na kwotę 15,3 mln zł (6\% ogólnej kwoty wydanych decyzji) ${ }^{30}$.

\footnotetext{
${ }^{28}$ Regiony Polski, GUS, Warszawa 2019, s. 52-53.

${ }^{29}$ Dane na dzień 31.10.2019, https://www.arimr.gov.pl/fileadmin/pliki/ wdrazane_programy_sprawozdania/M_4.1._MGR_Inwestycje_w_srodki_trwale-Wsparcie_inwestycji_w_gospodarstwach_rolnych._Modernizacja_gospodarstw_rolnych/20191130_M04.1_MGR_Wsparcie_inwestycji_w_gospodarstwach_rolnych_ zbiorczo_2_pdf [data dostępu: 30.11.2019].

${ }^{30}$ Dane na dzień 31.10.2019, https://www.arimr.gov.pl/fileadmin/pliki/ wdrazane_programy_sprawozdania/M_6.1._Premie_dla_mlodych_rolnikow/M_6.2_
} 
W drugim natomiast - 121 wniosków na kwotę prawie 50 mln zł, przy czym umowy zawarto z 80 rolnikami na kwotę $34 \mathrm{mln}$ zł (6\% ogólnej kwoty zawartych umów) ${ }^{31}$.

Rezultatem pozyskiwania wsparcia ze środków publicznych jest fakt, że w czerwcu 2016 roku w województwie podlaskim 1,7 tys. gospodarstw rolnych, czyli około 2,0\% ogółu, prowadziło pozarolniczą działalność gospodarczą, ale związaną z gospodarstwem rolnym ${ }^{32}$. Z badań prowadzonych przez Urząd Statystyczny w Białymstoku wynika, że działalność ta była odmienna w gospodarstwach zaliczanych do różnych grup obszarowych, to znaczy:

- „w grupie obszarowej 3-5 ha użytków rolnych dominowało rękodzieło (zajmowało się nim 87,3\% ogólnej liczby gospodarstw o takiej powierzchni użytków rolnych prowadzących działalność pozarolniczą),

- w grupie obszarowej 5-10 ha użytków rolnych znaczna część gospodarstw zajmowała się produkcją energii odnawialnej $(83,8 \%)$, przetwarzaniem surowego drewna w gospodarstwie (76,1\%), leśnictwem (69,4\%), agroturystyką (48,5\%), inną działalnością (34,3\%), nierolni-

Premie_na_rozpoczecie_dzialalnosci_pozarolniczej/20191130_M06.2_Premie_na_ rozpoczecie_dzialalnosci_pozarolniczej.pdf [data dostępu: 30.11.2019].

${ }^{31}$ Dane na dzień 31.10.2019, https://www.arimr.gov.pl/fileadmin/pliki/wdrazane_programy_sprawozdania/M_6.4._Wsparcie_inwestycji_w_tworzenie_i_rozwoj_dzialalnosci_pozarolniczej_Rozwoj_przedsiebiorczosci-_rozwoj_uslug_rolniczych_/20191130_M06.4_Rozwoj_przedsiebiorczosci-_rozwoj_uslug_rolniczych. pdf [data dostępu: 30.11.2019].

32 Warto dodać, że na potrzeby badań prowadzonych w związku z realizacją pracy doktorskiej, w 1995 roku autorka rozdziału przebadała ponad 320 gospodarstw rolnych, w których zidentyfikowała $5 \%$ gospodarstw rolnych prowadzących pozarolniczą działalność opartą na warsztacie rolnym. Gospodarstwa takie nazwała gospodarstwami wielofunkcyjnymi; zob. R. Przygodzka, dz. cyt. Oczywiście trudno porównywać te wskaźniki i na tej podstawie stwierdzić, że odsetek takich gospodarstw się zmniejszył. Byłoby to nieuprawnione. Niemniej jednak badania Urzędu Statystycznego bazują na działalności gospodarczej prowadzonej legalnie, natomiast badania ankietowe pozwoliły wychwycić również i aktywność niezarejestrowaną. Być może dlatego wskaźniki te się różnią. 
czymi pracami kontraktowymi z wykorzystaniem środków produkcji gospodarstwa $(23,9 \%)$,

- w grupie obszarowej 15-20 ha użytków rolnych najwięcej gospodarstw prowadziło przetwórstwo produktów rolnych $(21,1 \%)$,

- w grupie obszarowej 30-50 ha użytków rolnych znaczna część gospodarstw zajmowała się świadczeniem usług zawodowych, socjalnych i edukacyjnych $(44,4 \%)$ oraz rolniczymi pracami kontraktowymi z wykorzystaniem środków produkcji gospodarstwa (24,3\%). Najczęściej poszukiwano alternatywnych działalności w gospodarstwach należących do grupy obszarowej 5-10 ha użytków rolnych"33.

Niejako w konsekwencji w 2016 roku działalność pozarolnicza była głównym źródłem dochodów dla 8,0\% (w 2013 roku - 7,4\%) gospodarstw domowych z użytkownikiem gospodarstwa indywidualnego ${ }^{34}$.

\subsection{Analiza zmian przedsiębiorczości w badanych gminach}

Analizując zagadnienia dotyczące aktywności ekonomicznej obszarów wiejskich, należy wyraźnie podkreślić ich przestrzenne zróżnicowanie ${ }^{35}$. Teza ta jest prawdziwa zarówno w odniesieniu do rolnictwa, jak i pozarolniczej działalności gospodarczej. Dotyczy zarówno konkretnych województw, jak i gmin w nich usytuowanych. Ćwierć wieku temu, tj. w 1995 roku, autorka przeprowadziła szczegółowe badania w sześciu gminach ówczesnego województwa białostockiego. W tym miejscu należy wyjaśnić, jakie kryteria zadecydowały o ich zakwalifikowaniu do badań. Dobór celowy oparto na pięciu zasadniczych kryteriach: zróżnicowanie kategorii funkcjonalnych, zróżnicowanie demograficzne, zróżnicowanie warunków

${ }^{33}$ Charakterystyka gospodarstw rolnych $w$ województwie podlaskim $w 2016$ roku, Urząd Statystyczny w Białymstoku, Białystok 2017, s. 3.

${ }^{34}$ Tamże, s. 4.

${ }^{35}$ Zróżnicowanie to wynika z badań prowadzonych przez wielu autorów. 
produkcji rolniczej, poziomu działalności pozarolniczej, stopy bezrobocia zarejestrowanego. Kryteria te umożliwiły taki dobór gmin, który zapewnił w znacznym stopniu możliwość odnoszenia wyników badanych gmin do gmin o zbliżonych charakterystykach. Na podstawie powyższych kryteriów wytypowano następujące gminy:

- Suchowola - gmina miejsko-wiejska, zaliczona do kategorii funkcjonalnej ${ }^{36}$, do II rejonu demograficznego ${ }^{37}$, charakteryzująca się niższym od wojewódzkiego wskaźnikiem jakości rolniczej przestrzeni produkcyjnej $(52,6)$, średnią powierzchnią gospodarstwa wynoszącą 11,45 ha, jednym z najwyższych w województwie odsetkiem gospodarstw o powierzchni powyżej 15 ha (32,9\%), wskaźnikiem nasycenia podmiotami gospodarczymi wynoszącym 2,0 oraz przeciętną stopą bezrobocia $(12,2-14 \%)$;

- Juchnowiec Dolny - gmina wiejska, zaliczona do kategorii III i I rejonu demograficznego, charakteryzująca się wyższym od wojewódzkiego wskaźnikiem jakości rolniczej przestrzeni produkcyjnej wynoszącym

${ }^{36}$ Opierając się na metodzie typologii funkcjonalnej zaproponowanej przez Władysława Stolę, wyodrębniono 5 kategorii funkcjonalnych gmin województwa podlaskiego, obejmujących 44 gminy oraz 5 gmin, których nie można było zakwalifikować do żadnej z 5 kategorii funkcjonalnych. Były to: kategoria I - o dominującej funkcji rolniczej (19 gmin), kategoria II - o przewadze funkcji rolniczych z udziałem leśnictwa (13 gmin), kategoria III - o przewadze funkcji rolniczych z udziałem przemysłu i budownictwa (3 gminy), kategoria IV - o przewadze funkcji rolniczo-leśnych z udziałem przemysłu, kategoria V - o przewadze funkcji leśno-rolniczych z udziałem funkcji przemysłowych. R. Przygodzka, dz. cyt., s. 84-86.

${ }^{37}$ Na podstawie kilkunastu wskaźników opisujących sytuację demograficzną ówczesnego województwa białostockiego, wyodrębniono, w oparciu o metodę rejonizacji Warmusa, trzy rejony demograficzne. Rejon I charakteryzuje się wskaźnikami typowymi dla dynamicznej populacji (zakwalifikowano do niego 5 gmin przede wszystkim leżących w pobliżu Białegostoku). Rejon II charakteryzuje się wskaźnikami gorszymi w porównaniu z rejonem I, a populację określono jako stagnacyjną (zakwalifikowano 22 gminy). Natomiast do rejonu III zakwalifikowano gminy (23) o regresywnych wskaźnikach demograficznych. R. Przygodzka, dz. cyt., s. 57-59. 
59,2, jedną z najniższych przeciętną powierzchnią gospodarstwa wynoszącą 5,7 ha, bardzo niskim odsetkiem gospodarstw powyżej 15 ha $(7,9)$, wysokim wskaźnikiem nasycenia podmiotami gospodarczymi $(3,7)$ oraz wysoką stopą bezrobocia (powyżej 16\%);

- Sokółka - gmina miejsko-wiejska, zaliczona do I kategorii funkcjonalnej i II rejonu demograficznego, charakteryzująca się niższym niż wojewódzki wskaźnikiem waloryzacji rolniczej przestrzeni produkcyjnej $(51,7)$, zbliżoną do przeciętnej w województwie średnią powierzchnią gospodarstwa (9,1 ha), wysokim odsetkiem gospodarstw powyżej 15 ha $(22,9 \%)$, wskaźnikiem nasycenia w podmioty gospodarcze wynoszącym 1,6 oraz wysoką stopą bezrobocia (powyżej 16\%);

- Michałowo - gmina miejsko-wiejska, zaliczona do IV kategorii funkcjonalnej i III rejonu demograficznego, charakteryzująca się niskim wskaźnikiem waloryzacji rolniczej przestrzeni produkcyjnej (50,5), wyższą od wojewódzkiej przeciętną powierzchnią gospodarstwa (11,1 ha), przeciętnym w województwie odsetkiem gospodarstw powyżej 15 ha (19,1\%), przeciętnym wskaźnikiem nasycenia w podmioty gospodarcze wynoszącym 1,6, stopą bezrobocia powyżej 16\%;

- Brańsk - gmina wiejska, zaliczona do kategorii funkcjonalnej I i rejonu demograficznego III, charakteryzująca się najwyższym w województwie wskaźnikiem jakości rolniczej przestrzeni produkcyjnej $(64,10)$, typową dla województwa średnią powierzchnią gospodarstwa (9,25 ha), jak również typowym odsetkiem gospodarstw powyżej 15 ha (21,9\%), przeciętnym wskaźnikiem nasycenia podmiotami gospodarczymi wynoszącym 1,4 oraz stopą bezrobocia na poziomie 14,0\%;

- Nurzec Stacja - gmina wiejska, zaliczona do kategorii IV funkcjonalnej i II rejonu demograficznego, charakteryzująca się najniższym w województwie wskaźnikiem jakości rolniczej przestrzeni produkcyjnej $(47,5)$, niższą niż wojewódzka przeciętną powierzchnią gospodarstwa $(7,8)$, bardzo niskim odsetkiem gospodarstw o powierzchni powyżej 15 ha wynoszącym 10\%, przeciętnym wskaźnikiem nasycenia jednostkami gospodarczymi $(1,4)$ oraz najniższą stopą bezrobocia (poniżej $12 \%)$. 
Podstawowym miernikiem poziomu przedsiębiorczości jest liczba podmiotów gospodarki narodowej zarejestrowanych w REGON. W 2018 roku we wszystkich badanych gminach liczba tych podmiotów wyniosła 4063 (wykres 16.1.), co stanowiło 4\% ogółu podmiotów działających w województwie podlaskim. Największą liczbę podmiotów zarejestrowano w gminie Sokółka (gmina miejsko-wiejska) - 1942 oraz w gminie Juchnowiec Kościelny 1894. Łącznie podmioty w tych dwóch gminach stanowiły $77 \%$ ogółu.

Wykres 16.1. Podmioty gospodarki narodowej w rejestrze REGON w badanych gminach w latach 1995-2018

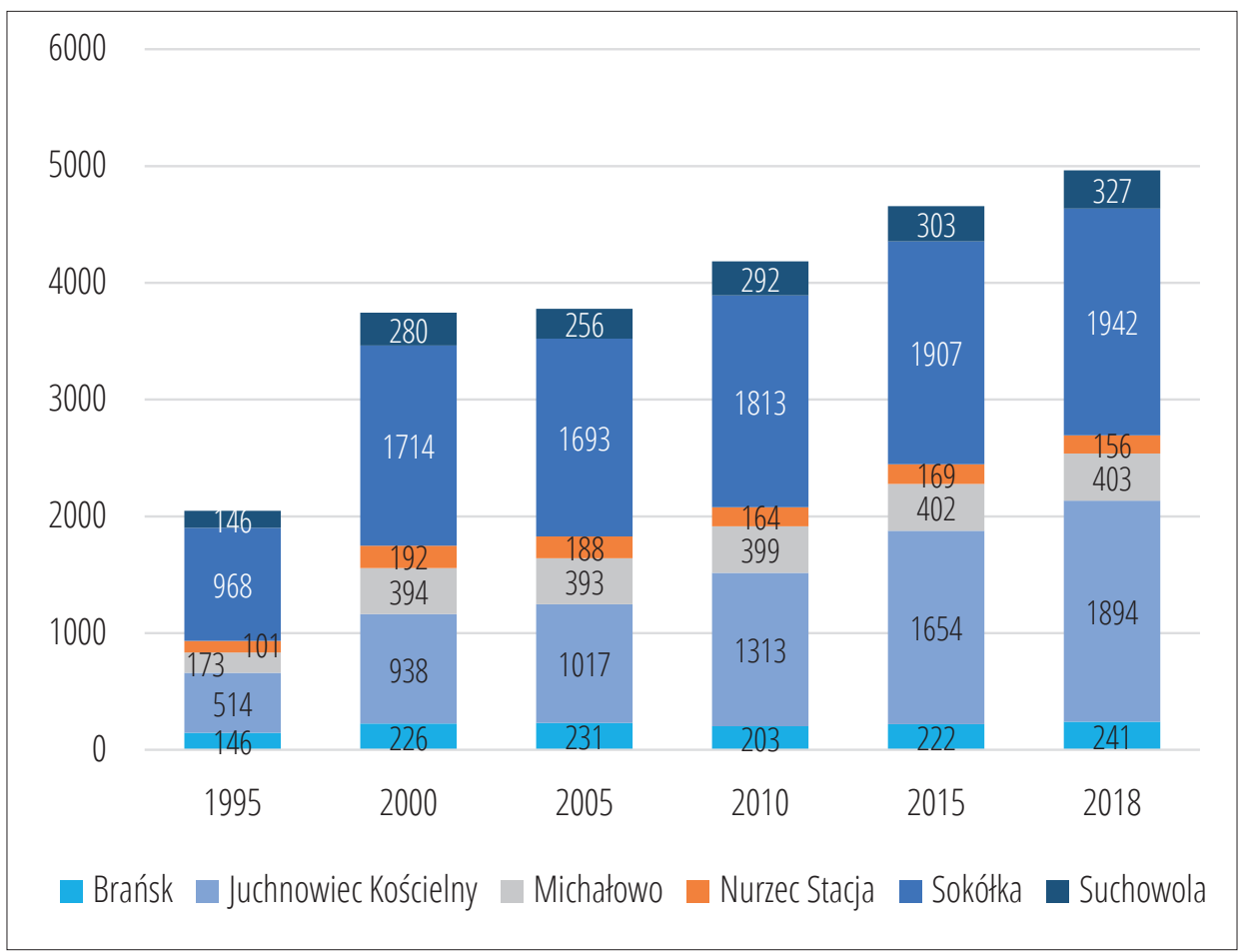

Źródło: opracowanie własne na podstawie Banku Danych Lokalnych.

W latach 1995-2018 we wszystkich badanych gminach liczba podmiotów gospodarczych wzrosła (wykres 16.1.), przy czym odmienne było tempo tych zmian (wykres 16.2.). 
Wykres 16.2. Dynamika zmian liczby podmiotów gospodarczych w badanych gminach w latach 1995-2018 (rok poprzedni $=100)$

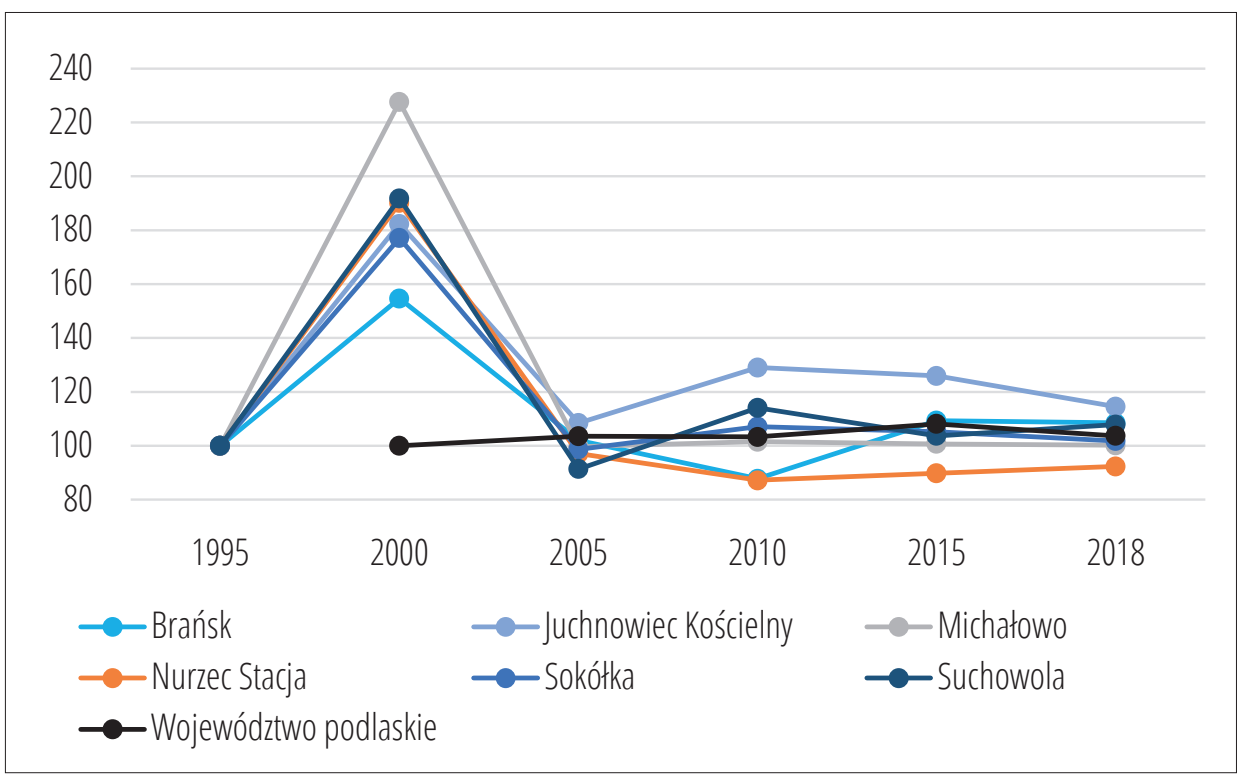

Źródło: opracowanie własne na podstawie Banku Danych Lokalnych.

W analizowanym okresie bardzo duży wzrost liczby podmiotów odnotowano między 1995 a 2000 rokiem $^{38}$. W gminie Michałowo wyniósł on aż $230 \%$, a w Suchowoli $191 \%$. Od tego momentu tempo wzrostu w większości gmin jest bardziej stabilne i kształtuje się przeciętnie na poziomie około 108\%. Wyjątek stanowią dwie gminy: gmina Nurzec Stacja, w której po dynamicznym wzroście liczby podmiotów w 2000 roku, tempo zmian utrzymuje się poniżej 100\%, co oznacza systematyczne kurczenie się aktywności ekonomicznej oraz gmina Juchnowiec Kościelny, w której zmiany mają odwrotną tendencję, tzn. indeks dynamiki rok do roku przekracza 120\%. Chociaż i w jednym, jak i drugim przypadku mamy

${ }^{38}$ Częstym zjawiskiem w tym czasie była konieczność przechodzenia pracowników różnych firm, w tym także Lasów Państwowych, które były ważnym pracodawcą w gminach o rozwiniętej funkcji leśnej, na tzw. samozatrudnienie, czego efektem był wzrost liczby osób prowadzących działalność gospodarczą. 
do czynienia z gminami wiejskimi, jednak na rozwój przedsiębiorczości wywiera wpływ tzw. renta lokalizacji ${ }^{39}$ - gmina Juchnowiec Kościelny jest gminą usytuowaną w pobliżu Białegostoku i to, co ją wyróżnia na tle pozostałych gmin, to jest rosnąca liczba mieszkańców na skutek migracji wewnętrznych między miastem a wsią (wykres 16.3.).

Wykres 16.3. Dynamika zmian liczby ludności w badanych gminach w latach 1995-2018 $($ rok $1995=100)$

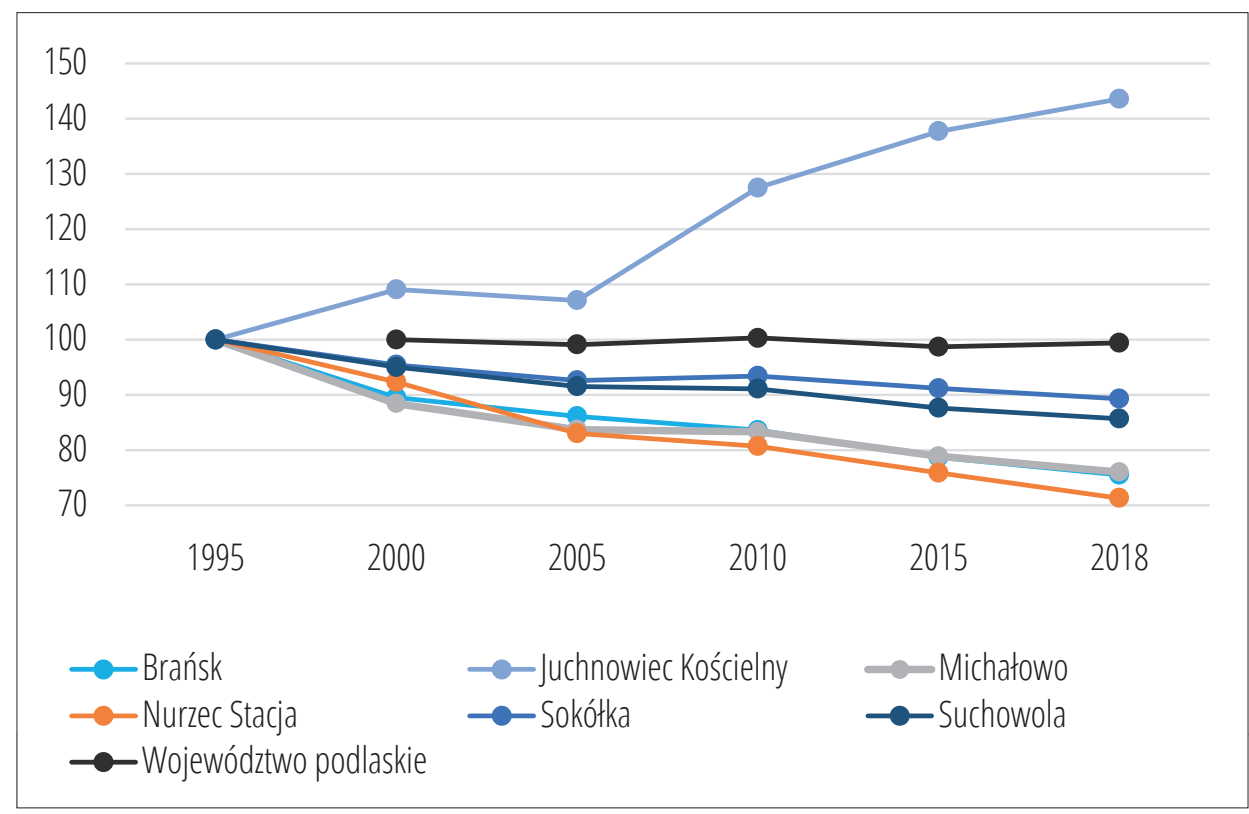

Źródło: opracowanie własne na podstawie Banku Danych Lokalnych.

Generalnie badane gminy w 2018 roku zamieszkiwało około 65 tys. osób, czyli 5\% ogółu mieszkańców województwa podlaskiego. Około 64\% mieszkańców badanych gmin zamieszkiwało gminy Sokółka i Juchnowiec Kościelny.

${ }^{39}$ Na prawidłowość powyższą wskazuje m.in. L. Ossowska, Zróżnicowanie poziomu przedsiębiorczości obszarów wiejskich województwa zachodniopomorskiego $w$ zależności od położenia wobec miast, "Journal of Agribusiness and Rural Development" 2015, nr 4(38), s. 814. 
W badanym okresie we wszystkich gminach, oprócz gminy Juchnowiec Kościelny, odnotowano spadek liczby mieszkańców. W największym stopniu procesy depopulacyjne wystąpiły w gminach: Nurzec Stacja (w porównaniu z rokiem 1995 liczba mieszkańców zmniejszyła się o 30\%), Brańsk (o 24,5\%) oraz Michałowo (o 24\%). Spośród badanych, jedyną gminą z dodatnim kierunkiem zmian była - wspomniana już - gmina Juchnowiec Kościelny. Liczba mieszkańców zwiększyła się w niej z 11379 do 16337, czyli o 43\%. Warto dodać, że już w roku 1995 gmina ta została zaliczona do I rejonu demograficznego, charakteryzującego się najkorzystniejszymi wskaźnikami ludnościowymi. Natomiast gminy Michałowo i Brańsk zaliczone zostały do rejonu III, czyli o najmniej korzystnych wskaźnikach demograficznych, co w zasadzie znajduje potwierdzenie w analizowanych danych. Największe „spadki” liczby ludności we wszystkich gminach wystąpiły do roku 2000 (wykres 16.4.), czyli w okresie, w którym występowała relatywnie wysoka stopa bezrobocia oraz wysoka stopa migracji zagranicznych.

Wykres 16.4. Dynamika zmian liczby ludności w badanych gminach w latach 1995-2018 (rok poprzedni $=100)$

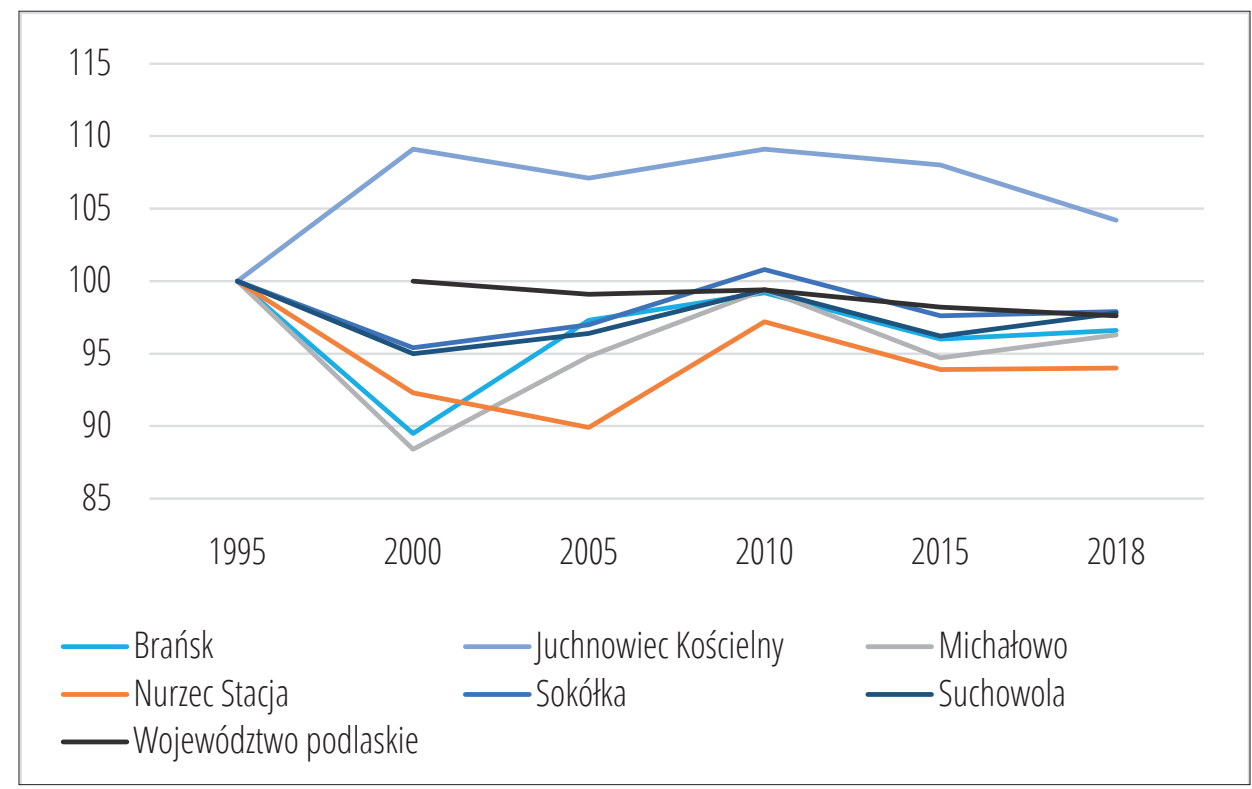

Źródło: opracowanie własne na podstawie Banku Danych Lokalnych. 
W literaturze podkreśla się, że jednym z najważniejszych czynników determinujących rozwój przedsiębiorczości jest ludność. W celu potwierdzenia powyższej tezy obliczono dla badanych gmin współczynnik korelacji. Poza gminą Nurzec Stacja, we wszystkich pozostałych gminach stwierdzono występowanie statystycznej zależności (bardzo dużej w przypadku gmin: Brańsk i Michałowo oraz dużej w przypadku gmin Juchnowiec Kościelny i Sokółka) pomiędzy dynamiką ludności a dynamiką podmiotów gospodarczych, przy czym w gminie Juchnowiec Kościelny jest to zależność dodatnia, czyli wzrostowi jednej cechy towarzyszy wzrost drugiej. W pozostałych gminach odnotowano zależność ujemną.

Tabela 16.1. Zależność między wskaźnikami dynamiki ludności a wskaźnikami dynamiki podmiotów gospodarczych w badanych gminach

\begin{tabular}{lc}
\hline Gmina & Współczynnik korelacji \\
\hline \hline Brańsk & $-0,963787985$ \\
\hline Juchnowiec Kościelny & 0,652287909 \\
\hline Michałowo & $-0,840499493$ \\
\hline Nurzec Stacja & - \\
\hline Sokółka & $-0,632627011$ \\
\hline Suchowola & $-0,533034308$
\end{tabular}

Źródło: opracowanie własne na podstawie danych z Banku Danych Lokalnych.

Miarą rozwoju przedsiębiorczości jest wskaźnik nasycenia podmiotami gospodarczymi. W poprzednim podpunkcie wskazano, że na tle kraju województwo podlaskie zajmuje przedostatnie miejsce pod tym względem. Ponieważ wskaźnik ten uwzględnia liczbę podmiotów gospodarczych odniesionych do liczby mieszkańców, stąd też najbardziej korzystny jego poziom występuje w gminach aktywnych. W 2018 roku najwyższą liczbę podmiotów na 100 mieszkańców odnotowano w gminie Juchnowiec Kościelny i wyniosła ona 11,5 (dwukrotnie więcej niż przeciętnie w województwie). Wyższy wskaźnik w porównaniu z regionem wystąpił także w gminie Sokółka $(7,6)$ 
oraz Michałowo (6,1). Ponieważ są to gminy miejsko-wiejskie stąd też należy przypuszczać, że działalność gospodarcza skupia się w nich głównie w miastach.

Dominującą formą organizacyjno-prawną podmiotów gospodarki w rejestrze REGON są osoby fizyczne prowadzące działalność gospodarczą. Ich udział w ogólnej liczbie podmiotów w 2018 roku w województwie podlaskim wynosił 77\%, natomiast w badanych gminach był nieznacznie wyższy i wyniósł 79\%. Jest to powszechne zjawisko, występujące na obszarach wiejskich całego kraju. Inną prawidłowością, która również znajduje potwierdzenie w badanych gminach, jest dominacja podmiotów w działalności określanej jako handel i naprawa pojazdów (wykres 16.5.). Kolejne miejsca zajmują budownictwo, przetwórstwo przemysłowe oraz transport i gospodarka magazynowa.

Wykres 16.5. Struktura osób fizycznych prowadzących działalność gospodarczą według sekcji PKD 2007 w badanych gminach w 2018 roku

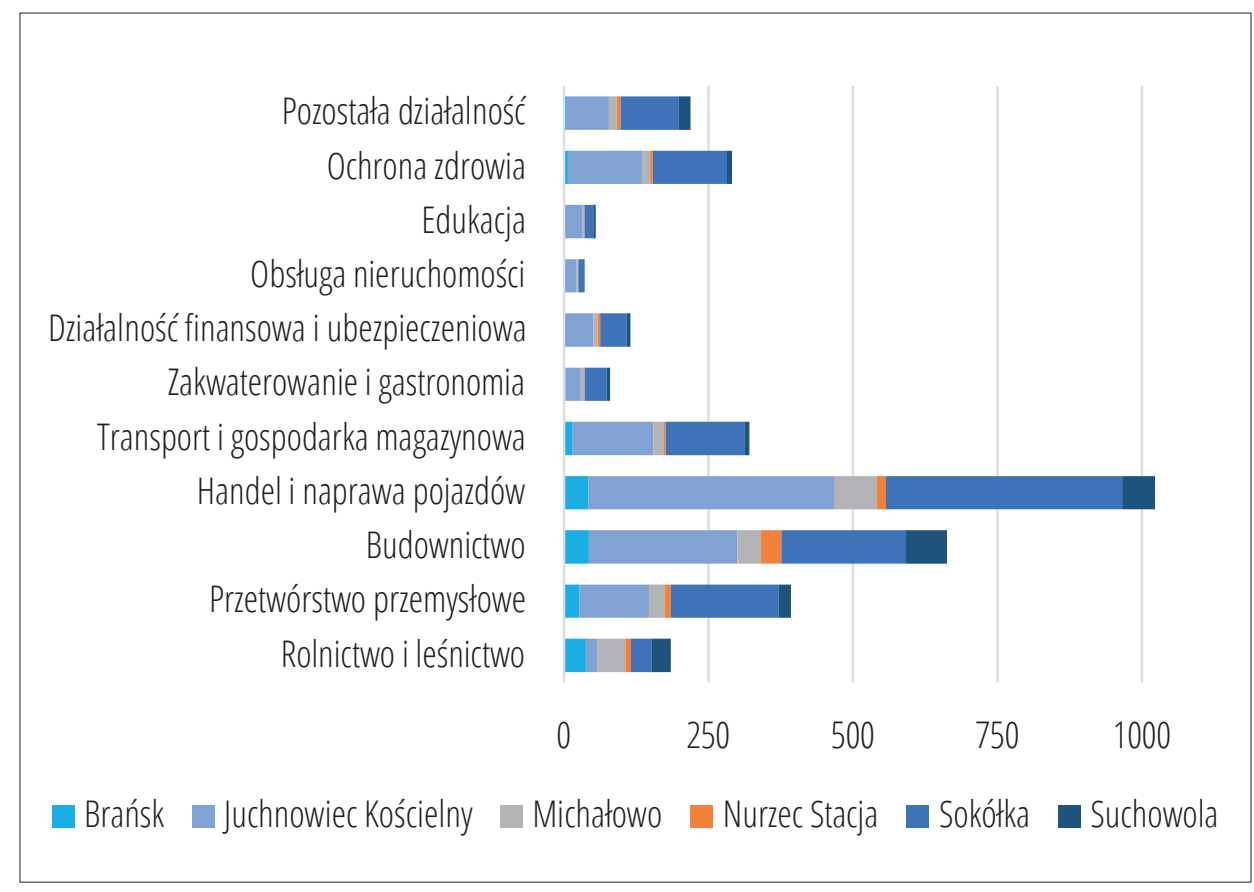

Źródło: opracowanie własne na podstawie Banku Danych Lokalnych. 
Chociaż zasadniczo obszary wiejskie charakteryzuje przede wszystkim działalność rolnicza, w związku z czym należałoby oczekiwać relatywnie dużej liczby podmiotów powiązanych z rolnictwem, okazuje się jednak, że ich odsetek nie przekracza 3\% ogółu podmiotów prowadzonych przez osoby fizyczne w badanych gminach, a największa liczba tych podmiotów występuje w gminie Michałowo. Relatywnie duża liczba podmiotów gospodarczych w gminach Sokółka i Juchnowiec Kościelny, ale też i większa liczba mieszkańców o zróżnicowanym popycie sprawiają, że w gminach tych daje się zaobserować większy przekrój prowadzonej działalności.

\section{Podsumowanie}

W podsumowaniu przeprowadzonych rozważań można sformułować następujące wnioski, które będą odpowiedziami na postawione we wstępie tego rozdziału pytania. Przede wszystkim należy stwierdzić, że w badanym okresie wzrosła (o około 23\%) liczba podmiotów gospodarki narodowej zarówno w całym województwie, jak i na obszarach wiejskich. Pomimo to, region pod względem nasycenia w podmioty gospodarcze plasuje się na przedostatnim miejscu w kraju. Podobnie jak w Polsce, około $30 \%$ podmiotów prowadzi działalność na wsi. Zbliżone do wskaźników krajowych są: struktura pod względem form organizacyjno-prawnych (dominują mikroprzedsiębiorstwa, a wśród nich działalność prowadzona przez osoby fizyczne) oraz struktura rodzajowa tej działalności (najwyższy jest odsetek działalności w handlu i naprawie pojazdów, budownictwie, przetwórstwie przemysłowym oraz transporcie i magazynowaniu). W badanych gminach natomiast, wprawdzie wszędzie w latach 1995-2018 wzrosła liczba podmiotów gospodarczych, jednak tempo tych zmian nie było jednakowe. Najwyższe tempo wzrostu charakteryzuje gminę usytuowaną w pobliżu Białegostoku, czyli stolicy regionu (gmina Juchnowiec Kościelny). Jest to jednocześnie gmina, w której jako jedynej spośród badanych, odnotowano wzrost liczby ludności. Przeciwieństwem niejako jest 
gmina Nurzec Stacja, w której następują poważne procesy depopulacyjne, a jednocześnie rozwój przedsiębiorczości wykazuje najsłabsze tempo. Zatem przeprowadzone badania potwierdzają ścisły związek między cechami demograficznymi społeczności lokalnej a poziomem przedsiębiorczości wiejskiej. 